DOI: 10.20472/IAC.2017.034.013

\author{
ANNAH CHILOANE \\ Southern Business School, South Africa \\ NICOLENE BARKHUIZEN \\ GIFT Research Niche Area North-West University, South Africa
}

\title{
EXPLORING THE RELATIONSHIP BETWEEN TALENT MANAGEMENT AND SERVICE DELIVERY IN A SELECTED GOVERNMENT INSTITUTION
}

\begin{abstract}
:
The main objective of this research was to determine the relationship between talent management and service quality of police officials. A Talent Management Measure and adapted version of the SERVQUAL were administered among police officials $(N=140)$. The results showed that more than half of the respondents were in agreement that talent retention practices need substantial improvement. The results further showed inadequate compensation, a lack of strategic talent management policies and talent development practices. About two-thirds of the participants were in agreement that performance management systems and talent attraction practices are somewhat adequate. The results showed a significant relationship between strategic talent management, performance management, talent retention, talent attraction, compensation and rewards, talent development and the assurance and reliability dimensions of service quality. Recommendations are made.
\end{abstract}

\section{Keywords:}

Police Officials, Talent Attraction, Talent Management, Talent Retention, Service Delivery

JEL Classification: J24 


\section{Introduction}

The stressful nature of police work is well documented. Police officials are exposed to personal danger, discomfort, severe trauma and anxiety during crime prevention operations (Masiapata, 2007). Maintaining the police workforce level is becoming a great challenge in the midst of high rates of suicide, alcoholism, burnout, and absenteeism within the profession (Myendeki, 2008; Paulsen, 2008). Consequently police officials are in drastic need of a supporting work environment that can assist them to cope with the presures that are part of their daily work.

The main objective of this research was to determine the relationship between the talent management and quality service delivery of police officials. More specifically this research aimed at addressing the following research questions:

- What are the perceptions of police officials regarding the current application of talent management in their workplace?

- What are the perceptions of police officials regarding the quality service delivery in their workplace?

- To what extent does talent management influence the quality service delivery of police officials?

Recently the South African Police Service (SAPS) implemented a service delivery improvement plan with the aim to deliver "An efficient, effective and developmentorientated public service, which espouses the need for quality and access to service delivery by the government" (SAPS, 2015: 5). This plan further proposed that the SAPS recruit and train officials to be professional, impartial and competent in their work when serving the community (Faull, 2017).

Despite these initiatives, the quality service delivery of the SAPS remains a challenge. According to Gopal, Mbongwe and Marimuthu (2015) results from available studies confirm that the service that clients receive from the SAPS is of poor quality. Poor services ranged from complaints about the police not doing their jobs, unacceptable behaviour towards the public, slow response times and lack of responsibility (Vilakazi, 2015). Talent managament has been identified as an enabler for service delivery and organisational performance (see Barkhuizen, 2015). We therefore belief that talent management can play a significant role in the enhancement of quality service delivery of police officials. 


\section{Literature Review \\ Talent Management}

Abdul-Kareem (2016) describes talent management as a process to ensure that organisations have the right number of people and the right kind of people at the right place capable of meeting current and future business priorities. Barkhuizen (2015) defines talent management as a strategic business process that incorporates the effective management of the career life cycle of skilled and key employees from start to finish. More specifically Cannon and McGee (2011) belief that talent management can be effectively applied by:

- developing a strategy to determine what the organisation needs to meet the current and future demands of the business plan;

- establishing processes that measure the available and required competence;

- creating a range of developmental tools and processes to provide tailored approaches depending on the individual needs of employees;

- identifying ways to obtain and retain those who are critical to success;

- establishing appropriate approaches dealing with those who no longer fit organisational requirements

A study by Schwartz, Schurink and Stanz (2007) showed that frontline police officials were not committed to their jobs anymore even though the SAPS tried to retain employee commitment through rapid promotions. Moreover policy implementation to redress equity in conjunction with unfair promotion practices, transfers and rewards were a major cause of dissatisfaction and lack of effective service delivery.

\section{Talent Management Practices}

A great deal of research has been devoted towards detecting the most prominent talent management practices in Southern African government institutions. Research to date identified the following practices as key to the effective management of talented employees in the workplace: Management Commitment, Talent Acquisition, Workforce Planning, Talent Development, Performance Management, Rewards and remuneration and Talent Retention. In what follows next a brief description of each of these practices are presented and its relevance to the government sector.

Management Commitment: According to McCauley and Wakefield (cited in van Dijk, 2008) the commitment of senior managers is a key ingredient for talent management practices to excel in organisations. Studies showed that management mindset towards talent management was a significant predictor of the turnover intentions of younger generation and early career talent (Du Plessis, Barkhuizen, Stanz \& Schutte, 2015; Lesenyeho, 2017; Matobako \& Barkhuizen, 2017). Management support for talent management also played an important role in enhancing positive work related behaviours 
such as organisational commitment (Lesenyeho, 2017), job and organisational satisfaction (Barkhuizen, Schutte \& Nagel, 2017; Magolego, Barkhuizen \& Lesenyeho, 2013; Theron, Barkhuizen \& Du Plessis, 2014) and ultimately organisational performance (Masale, Barkhuizen, Mokgele \& Makgala, 2016). To date the majority of studies in government institutions highlighted the need for more management commitment towards talent management to enhance quality service delivery (Schutte \& Barkhuizen, 2016).

Workforce planning: Armstrong and Taylor (as cited by Ncube, 2016) define workforce planning as a core process of human resource management that is shaped by organisational strategy and ensures the right number of people with the right skills, in the right place at the right time to deliver short and long-term organisational objectives. According to Mogwere (2014), workforce planning is about predicting who will be the key drivers of the organisation's future success. Poor workforce planning and forecasting of future talent needs can have a detrimental effect on any organisation (Barkhuizen, Welby-Cooke, Stanz \& Schutte, 2015). Strauss (2012) found that a shortage of teachers in rural schools had an important impact on the ability of the remaining teachers to perform in their jobs and meet the expectations of school children.

Talent acquisition: Talent acquisition is regarded as a process of finding and acquiring skilled human labour for organisational needs and to meet any labour requirements (Kumudha \& Priyadarshin, 2016). Ineffective recruitment precludes any chance for effective candidates' selection because when recruitment falls short, selection must proceed with a pool of poorly qualified candidates (Kahn \& Louw, 2010). Saurombe, Barkhuizen and Schutte (2017) found that a compelling organisational brand is crucial for the attraction of key and competent employees.

Talent development: According to Born and Heers (2009) training and development are crucial as far as talent management is concerned. Appropriate learning and development interventions are needed in relevant stages of a career path of talented individuals to achieve their maximum potential (Mello, 2008). Barkhuizen (2014) found that opportunities for career development and further training are main factors for generation $Y$ employees when selecting their employer of choice. Likewise a study by Lesenyeho (2017) showed that the availability of training and development opportunities enhanced the talent retention of early career academics. Clearly career planning and development are important tools in developing and retaining an effective workforce.

Performance management: Dhanabhakyam and Kokilambal (2014) regard performance management as the process through which supervisors and those they lead gain a shared understanding of work expectations and goals, exchange performance feedback, identify learning and development opportunities, and evaluate performance results. A good performance management system can act as a positive method to identify 
developmental opportunities and implement a succession planning process (Mondy, Noe \& Premeaux, as cited in Makhuzeni \& Barkhuizen, 2015). Organisations that do not focus on performance management at all levels have difficulty to find competitive advantage through talent (Lawler \& Ulrich, 2008). Makhuzeni and Barkhuizen (2015) found that effective performance management systems are important for the retention of school teachers in public schools.

Compensation and rewards: According to Reddick and Coggburn (2008) the aim of the total compensation system is to achieve the following goals among others: attracting employees, retaining solid performers, motivating performance, spending compensation money wisely, aligning employees with goals of the organisation and rewarding the behaviour that the organisation wants to encourage. Hewitts (2008) maintain that a high performance workforce can be achieve when accountability for results and opportunities for rewards and advancement are aligned. Nthebe, Barkhuizen and Schutte (2016) and Makhuzeni and Barkhuizen (2015) recommend the application of a total rewards strategy for the public sector consisting of a combination of compensation, benefits, work-life balance, training and development opportunities and effective performance management systems.

Talent retention: The retention of a talented workforce remains a significant challenge for many public sector institutions in South Africa (Barkhuizen, 2015). Phillips and Cornell (cited in Born and Heers, 2009) define retention as the percentage of employees that are remaining in the organisation. Nafei (2015) is of the opinion that a positive talent culture contributes to the retention of employees. The trend to emerge is that many government institutions do not have talent retention strategies in place to retain top talent. This in turn poses a significant risk for the performance and sustainability of the government (Madimabe, Barkhuizen \& Schutte, 2017). Government institutions furthermore experience a significant loss of knowledge due to the high staff turnover at management level (Public Service Commision Report, 2015). Government institutions should therefore develop talent retention policies and practices that will attract new employees, satisfy older generation of employees and motivate current employees to stay with the organisation (Barkhuizen, 2014).

\section{Service Quality}

The most prominent definition of service quality was coined by Parasuraman and colleagues (see Parasuraman, Zeithaml \& Berry, 1990) to measure the service delivered against expected service performance. According to Munusamy et al. (as cited by Nafei, 2015) service quality is referred to as the difference between customer's expectations of the service encounter and the perception of the service received. The South African government uses the Batho Pele (People First) principles to ensure that quality service is provided to all people in South Africa. These principles include Consultation, Service 
Standard, Access, Courtesy, Information, Openness and Transparency, Redress and Value for money (Mello, 2008).

Service quality can be measured in terms of five main dimensions, namely, tangibles, assurance, responsiveness, reliability and empathy (Parasuraman et al. 1990). Tangibles refer to the appearance of physical facilities, equipment, personnel and communication materials. Assurance refers to knowledge and courtesy of employees and their ability to convey trust and confidence. Responsiveness refers to the willingness of employees to help customers and provide prompt service. Reliability refers to the ability to perform the promised service dependably and accurately. Empathy refers to the caring, individualised attention that organisations provide to their customers.

Schwartz, Schurink and Stanz, (2008) found that quality services in the police force are undermined because of perceived unfairness relating to organisational change processes and a lack of resources (Schwartz et al., 2007). A study by Masiapata (2007) revealed that ethics education and training, good incentive structures, effective performance appraisals and organisational culture reform can enhance positive work ethos and ethics of police officials. Matobako and Barkhuizen (2017) found that talent management is an important factor for the motivation and retention of junior correctional officials.

\section{Relating Talent Management and Service Quality}

A great deal of managers, practitioners and researchers advocate that talent management is the key to business competitiveness and sustainability. Limited empirical research exist to confirm the above notion. Studies by Masale et al. (2017) and Magolego et al. (2013) showed that poor talent management practices significantly reduces the performance of employees. A study by Barkhuizen, Schutte and Smit (2015) among support staff in a public higher education institution showed that talent management practices such as staffing enhanced the reliability and empathetic dimensions of quality service delivery. In the same study a lack of talent retention strategies reduced the ability of staff to deliver timely (responsive) service in an environment that is not conducive for quality service delivery (tangibility). A study by Nthebe et al (2016) among public school principals showed that effective performance management enhanced the reliability of quality service orientation. In the same study adequate benefits enhanced the assurance and reliability dimensions of service quality. Simasiku and Schutte (2017) found that high workloads significantly reduced the reliable and responsiveness dimensions of service quality whereas colleague support enhanced responsiveness to service in a Namibian parastatal.

H 1: Talent Management would be positively related to service quality 


\section{Research Design \\ Research Approach}

The research utilised a quantitative research approach. Since it is practically impossible to collect information from all SAPS employees, as the SAPS have departments (Provinces/Divisions/Components) nationally, three divisions were used for study. The researcher used a non-experimental cross-sectional method as the aim was to explore the relationship between two variables namely, talent management and service delivery in the SAPS. A. cross-sectional study is also identified as one-shot or a status study, which is designed to study some phenomenon by taking a cross-section of it at a time (Kumar, 2014). Two variables were identified, talent management being an independent variable and service delivery a dependent variable, which means that the research is correlational. Surveys were used to collect the data.

\section{Research Participants}

The participants used for the study were SAPS employees, both those employed under the Police Service Act and under the Public Service Act, irrespective of salary levels or rank, both male and female, of all races, permanent and non-permanent. Employees were chosen using a probability sampling method. Probability sampling means a sample selection whereby each member of the population had an equal chance of being chosen (Leedy \& Ormrod, 2015). Two hundred questionnaires were distributed to a random sample of employees who were chosen from the already existing lists (generated system report) from the Human Resource Management section of the three divisions. The participants were included because they have knowledge of the policies and what is happening around them, so they will provide the information required honestly. This research meet all ethical requirements.

In total of 140 questionnaires were returned, with all being usable for statistical analysis. This represents a response rate of $70 \%$. The demographic characteristics of the participants are presented in Table 1 below. 
Table 1: Descriptive Statistics of the Measuring Instruments

\begin{tabular}{|c|c|c|c|}
\hline & Category & Frequency & Percentage \\
\hline \multirow[t]{2}{*}{ Gender } & Male & 71 & 50,7 \\
\hline & Female & 69 & 49,3 \\
\hline \multirow[t]{3}{*}{ Language } & Afrikaans & 38 & 27,1 \\
\hline & English & 9 & 6,4 \\
\hline & Indigenous & 93 & 66,4 \\
\hline \multirow[t]{4}{*}{ Race } & African & 92 & 65,7 \\
\hline & Coloured & 5 & 3,6 \\
\hline & Indian & 7 & 5,0 \\
\hline & White & 35 & 25,0 \\
\hline \multirow[t]{4}{*}{ Age } & $20-29$ years & 22 & 15,7 \\
\hline & 30 - 39 years & 21 & 15,0 \\
\hline & 40 - 49 years & 49 & 35,0 \\
\hline & 50 years plus & 29 & 20,7 \\
\hline \multirow{6}{*}{ Qualifications } & Matric & 14 & 10,0 \\
\hline & Certificate & 42 & 30,0 \\
\hline & Diploma & 10 & 7,1 \\
\hline & $\begin{array}{l}\text { Advanced } \\
\text { Diploma }\end{array}$ & 31 & 22,1 \\
\hline & Bachelors & 11 & 7,9 \\
\hline & Postgraduate & 31 & 22,1 \\
\hline \multirow{4}{*}{ Job level } & Operational & 71 & 50,7 \\
\hline & Supervisory & 6 & 4,3 \\
\hline & $\begin{array}{l}\text { Middle } \\
\text { Management }\end{array}$ & 17 & 12,1 \\
\hline & $\begin{array}{l}\text { Senior } \\
\text { Management }\end{array}$ & 42 & 30,0 \\
\hline \multirow{4}{*}{ Years in Police } & 0 to 10 years & 53 & 37,9 \\
\hline & 11 to 20 years & 36 & 25,7 \\
\hline & 21 to 30 years & 44 & 31,4 \\
\hline & $\begin{array}{l}30 \text { years and } \\
\text { more }\end{array}$ & 7 & 5,0 \\
\hline
\end{tabular}


Years in Current Job

\begin{tabular}{|l|c|c|}
0 to 10 years & 97 & 69,3 \\
\hline 11 to 20 years & 29 & 20,7 \\
\hline 21 to 30 years & 13 & 9,3 \\
\hline
\end{tabular}

Most of the participants in this sample were male $(50,7 \%)$ with indigenous languages as their main home language $(66,4 \%)$. The participants were primarily representative of the African ethnic group (65,7\%), aged between 40 and 49 years (35\%) and in possession of a Certificate as their highest level of educational qualification (30\%). The majority of the participants were employed at operational level (50,7\%), employed between 0 to 10 years $(37,9 \%)$ in the police force and employed between 0 to 10 years in their current job $(69,3 \%)$.

\section{Measuring Instruments}

Talent management Questionnaire: A talent management questionnaire was used to measure the respondents' perceptions of talent management practices in the organisation (Barkhuizen, 2015). The questionnaire consisted of 34 items and measured eight talent management practices namely management commitment, workforce planning, staffing, talent acquisition, talent development, compensation and rewards, performance management and talent retention. Respondents were required to assess the current state of application of talent management practices on a six-point Likert scale, ranging from strongly disagree (1) to strongly agree (6). This questionnaire has been valid and reliable in several South African studies (see Barkhuizen, 2015).

SERVQUAL: An adapted version of the SERVQUAL (Parasuraman et al., 1990) was used to measure service quality. The questionnaire consists of 11 items and measures five service quality dimensions, namely reliability, responsiveness, assurance, empathy and tangibility on a six-point Likert-type scale. The questionnaire was validated in South African context (Nthebe et al., 2016).

\section{Research Procedure}

Permission was obtained from the necessary authorities, namely Divisional Commissioners: Research, Finance and Administration Services, Personnel Management and Human Resource Utilisation in order to undertake the research prior to the administration of the questionnaires. Permission was also obtained from the supervisors of the participants and participants themselves. The purpose of the research 
was explained to Section Heads and participants. For the sake of convenience, survey questionnaires were distributed electronically (emailed) and hand delivered (hard copy) to participants. For feedback purposes, completed questionnaires were emailed back and collected. Participation was voluntary and confidential.

\section{Statistical analysis}

The data was analysed using SPSS.24 (SPSS, 2017). Descriptive statistics (i.e. frequencies, means, standard deviations, skewness and kurtosis) were applied. Exploratory factor analyses, using varimax rotation, was used to determine the factor structure of the measuring instruments. Cronbach alphas were used to determine the reliability of the measuring instruments. A cut-off point of $\alpha \geq 0,70$ was used. Pearson correlations were used to determine the relationships between talent management and service delivery.

\section{Results}

A Principal components analysis was done on the 34 items of the Talent Management Measure. The initial results showed that six factors could be extracted, based on the eigenvalues. A subsequent principal components analysis was done, using varimax rotation, to specify six factors. Four items were deleted because of problematic loadings. The six factors explained $67,460 \%$ of the variance, and were labelled Strategic Talent Management (Factor 1), Compensation and Rewards (Factor 2), Performance Management (Factor 3), Talent Retention (Factor 4), Career Development (Factor 5) and Talent Attraction (Factor 6). All items showed acceptable loadings. The results of the Total variance explained of the measure and the rotated component matrix are reported in Tables 2 and 3 below.

Table 2: Total variance explained for the Talent Management Instrument

\begin{tabular}{|l|c|c|c|c|c|c|}
\hline \multirow{2}{*}{ Component } & \multicolumn{3}{|c|}{ Initial Eigenvalues } & \multicolumn{3}{c|}{ Extraction Sums of Squared Loadings } \\
\cline { 2 - 7 } & Total & \% of Variance & $\begin{array}{c}\text { Cumulative } \\
\%\end{array}$ & Total & $\begin{array}{c}\text { \% of } \\
\text { Variance }\end{array}$ & $\begin{array}{c}\text { Cumulative } \\
\%\end{array}$ \\
\hline 1 & 10,981 & 36,602 & 36,602 & 10,981 & 36,602 & 36,602 \\
\hline 2 & 3,442 & 11,475 & 48,076 & 3,442 & 11,475 & 48,076 \\
\hline 3 & 1,930 & 6,434 & 54,511 & 1,930 & 6,434 & 54,511 \\
\hline 4 & 1,415 & 4,717 & 59,228 & 1,415 & 4,717 & 59,228 \\
\hline 5 & 1,366 & 4,554 & 63,783 & 1,366 & 4,554 & 63,783 \\
\hline
\end{tabular}




\begin{tabular}{|c|c|c|c|c|c|c|}
\hline 6 & 1,103 & 3,678 & 67,460 & 1,103 & 3,678 & 67,460 \\
\hline 7 & 1,011 & 3,370 & 70,830 & & & \\
\hline 8 & 0,902 & 3,008 & 73,838 & & & \\
\hline 9 & 0,774 & 2,581 & 76,419 & & & \\
\hline 10 & 0,672 & 2,240 & 78,659 & & & \\
\hline 11 & 0,629 & 2,095 & 80,754 & & & \\
\hline 12 & 0,569 & 1,897 & 82,651 & & & \\
\hline 13 & 0,535 & 1,782 & 84,433 & & & \\
\hline 14 & 0,466 & 1,553 & 85,986 & & & \\
\hline 15 & 0,455 & 1,515 & 87,501 & & & \\
\hline 16 & 0,430 & 1,435 & 88,936 & & & \\
\hline 17 & 0,402 & 1,341 & 90,278 & & & \\
\hline 18 & 0,391 & 1,304 & 91,581 & & & \\
\hline 19 & 0,366 & 1,221 & 92,803 & & & \\
\hline 20 & 0,322 & 1,074 & 93,877 & & & \\
\hline 21 & 0,307 & 1,025 & 94,902 & & & \\
\hline 22 & 0,250 & 0,835 & 95,736 & & & \\
\hline 23 & 0,223 & 0,744 & 96,480 & & & \\
\hline 24 & 0,214 & 0,713 & 97,193 & & & \\
\hline 25 & 0,174 & 0,579 & 97,772 & & & \\
\hline 26 & 0,170 & 0,566 & 98,338 & & & \\
\hline 27 & 0,140 & 0,467 & 98,805 & & & \\
\hline 28 & 0,134 & 0,445 & 99,250 & & & \\
\hline 29 & 0,114 & 0,380 & 99,631 & & & \\
\hline 30 & 0,111 & 0,369 & 100,000 & & & \\
\hline
\end{tabular}

Table 3: Varimax Rotation for the Talent Management Measure

\begin{tabular}{|l|c|c|c|c|c|c|}
\hline & \multicolumn{5}{|c|}{ Component } \\
\cline { 2 - 7 } & $\begin{array}{c}\text { Strategic } \\
\text { Talent } \\
\text { Management }\end{array}$ & $\begin{array}{c}\text { Compensation } \\
\text { \& } \\
\text { Rewards }\end{array}$ & $\begin{array}{c}\text { Performance } \\
\text { Management }\end{array}$ & $\begin{array}{c}\text { Talent } \\
\text { Retention }\end{array}$ & $\begin{array}{c}\text { Career } \\
\text { Development }\end{array}$ & $\begin{array}{c}\text { Talent } \\
\text { Attraction }\end{array}$ \\
\hline TLM1 & $\mathbf{0 , 7 3 4}$ & $-0,098$ & 0,014 & 0,072 & 0,334 & 0,202 \\
\hline TLM2 & $\mathbf{0 , 8 0 2}$ & $-0,076$ & 0,048 & 0,011 & 0,288 & 0,037 \\
\hline TLM3 & $\mathbf{0 , 7 8 2}$ & $-0,067$ & 0,020 & 0,181 & 0,203 & 0,147 \\
\hline TLM4 & $\mathbf{0 , 7 5 3}$ & 0,070 & $-0,004$ & 0,285 & 0,259 & 0,098 \\
\hline
\end{tabular}




\begin{tabular}{|c|c|c|c|c|c|c|}
\hline TLM5 & 0,798 & 0,046 & 0,081 & 0,397 & 0,087 & $-0,001$ \\
\hline TLM6 & 0,640 & 0,266 & 0,121 & 0,313 & 0,065 & 0,015 \\
\hline TLM7 & 0,654 & 0,252 & 0,256 & 0,187 & 0,016 & 0,191 \\
\hline TLM8 & 0,603 & 0,038 & 0,070 & 0,217 & 0,038 & 0,390 \\
\hline TLM9 & 0,632 & 0,069 & 0,025 & 0,195 & $-0,013$ & 0,350 \\
\hline TLM10 & 0,783 & 0,078 & 0,190 & 0,108 & 0,011 & 0,202 \\
\hline TLM11 & 0,556 & 0,318 & 0,241 & 0,090 & $-0,060$ & 0,233 \\
\hline TLM12 & 0,423 & 0,156 & 0,184 & $-0,150$ & 0,012 & 0,571 \\
\hline TLM13 & 0,437 & 0,130 & 0,205 & 0,093 & $-0,052$ & 0,551 \\
\hline TLM14 & 0,304 & 0,112 & $-0,043$ & 0,150 & 0,392 & 0,681 \\
\hline TLM15 & 0,394 & 0,210 & 0,065 & 0,327 & 0,205 & 0,510 \\
\hline TLM20 & 0,313 & 0,291 & 0,236 & 0,139 & 0,638 & 0,097 \\
\hline TLM21 & 0,181 & 0,315 & 0,203 & $-0,020$ & 0,734 & 0,084 \\
\hline TLM22 & 0,083 & 0,284 & 0,133 & 0,177 & 0,729 & 0,060 \\
\hline TLM23 & $-0,132$ & 0,132 & 0,545 & 0,163 & 0,023 & 0,509 \\
\hline TLM24 & 0,041 & 0,051 & 0,842 & 0,069 & 0,030 & 0,169 \\
\hline TLM25 & 0,246 & 0,095 & 0,739 & 0,096 & 0,190 & 0,036 \\
\hline TLM26 & 0,201 & 0,151 & 0,767 & $-0,028$ & 0,247 & $-0,036$ \\
\hline TLM27 & 0,044 & 0,708 & 0,084 & 0,034 & 0,334 & 0,198 \\
\hline TLM28 & $-0,024$ & 0,842 & 0,105 & 0,077 & 0,083 & 0,127 \\
\hline TLM29 & 0,062 & 0,902 & 0,092 & 0,067 & 0,124 & 0,031 \\
\hline TLM30 & 0,173 & 0,798 & 0,077 & 0,136 & 0,279 & 0,056 \\
\hline TLM31 & 0,253 & 0,149 & 0,082 & 0,527 & 0,250 & 0,302 \\
\hline TLM32 & 0,258 & 0,113 & 0,169 & 0,714 & $-0,012$ & 0,196 \\
\hline TLM33 & 0,564 & 0,185 & 0,072 & 0,570 & 0,029 & $-0,046$ \\
\hline TLM34 & 0,335 & 0,014 & $-0,025$ & 0,768 & 0,134 & $-0,029$ \\
\hline
\end{tabular}


A principal components analyses were done on the 11 items of the SERVQUAL. The initial results showed that two factors could be extracted, based on the eigenvalues. A subsequent principal components analysis was done, using varimax rotation, to specify two factors. The two factors explained $71,876 \%$ of the variance, and were labelled Reliability (Factor 1), and Assurance (Factor 2). All items showed acceptable loadings. The results of the Total Variance explained for the measure and the rotated component matrix are reported in Tables 4 and 5 below.

Table 4: Total variance explained for the SERVQUAL

\begin{tabular}{|l|c|c|c|c|c|c|}
\hline \multirow{2}{*}{ Component } & \multicolumn{3}{|c|}{ Initial Eigenvalues } & \multicolumn{3}{c|}{ Extraction Sums of Squared Loadings } \\
\cline { 2 - 7 } & Total & \% of Variance & $\begin{array}{c}\text { Cumulative } \\
\%\end{array}$ & Total & $\begin{array}{c}\text { \% of } \\
\text { Variance }\end{array}$ & $\begin{array}{c}\text { Cumulative } \\
\%\end{array}$ \\
\hline 1 & 6,809 & 61,903 & 61,903 & 6,809 & 61,903 & 61,903 \\
\hline 2 & 1,097 & 9,974 & 71,876 & 1,097 & 9,974 & 71,876 \\
\hline 3 & 0,717 & 6,518 & 78,394 & & & \\
\hline 4 & 0,541 & 4,920 & 83,314 & & & \\
\hline 5 & 0,427 & 3,885 & 87,200 & & & \\
\hline 6 & 0,358 & 3,259 & 90,458 & & & \\
\hline 7 & 0,296 & 2,692 & 93,151 & & & \\
\hline 8 & 0,275 & 2,499 & 95,650 & & & \\
\hline 9 & 0,222 & 2,018 & 97,669 & & & \\
\hline 10 & 0,150 & 1,366 & 99,034 & & & \\
\hline 11 & 0,106 & 0,966 & 100,000 & & & \\
\hline
\end{tabular}

Table 5: Varimax rotation for the SERVQUAL

\begin{tabular}{|l|c|c|}
\hline & Reliability & Assurance \\
\hline SD1 & 0,311 & 0,757 \\
\hline SD2 & 0,122 & 0,893 \\
\hline SD3 & 0,825 & 0,202 \\
\hline SD4 & 0,589 & 0,263 \\
\hline SD5 & 0,821 & 0,271 \\
\hline SD6 & 0,841 & 0,133 \\
\hline SD7 & 0,892 & 0,176 \\
\hline SD8 & 0,894 & 0,101 \\
\hline SD9 & 0,805 & 0,321 \\
\hline
\end{tabular}




\begin{tabular}{|l|l|l|}
\hline SD10 & 0,792 & 0,331 \\
\hline SD11 & 0,779 & 0,291 \\
\hline
\end{tabular}

The descriptive statistics of the measuring instruments are reported in Table 6 below. The results showed acceptable to excellent reliabilities for the factors. The results show that more than half of the respondents were in agreement that talent retention practices are poorly applied. This is followed by poor perceived compensation, strategic talent management practices, and talent development practices. About two-thirds of the sample were in agreement that performance management systems and talent attraction practices are somewhat adequate.

Table 6: Descriptive statistics of the Measurements

\begin{tabular}{|l|c|c|c|c|c|}
\hline & Mean & $\begin{array}{c}\text { Std. } \\
\text { Deviation }\end{array}$ & Skewness & Kurtosis & $\alpha$ \\
\hline \multicolumn{7}{|c|}{ TALENT MANAGEMENT PRACTICES } \\
\hline Strategic Talent Management & 3,3318 & 1,06844 & $-0,275$ & $-0,758$ & 0,932 \\
\hline Compensation & 3,1214 & 1,19520 & 0,119 & $-0,712$ & 0,889 \\
\hline Performance Management & 4,4125 & 0,95958 & $-0,497$ & 0,344 & 0,784 \\
\hline Talent Retention & 2,9875 & 1,11454 & 0,240 & $-0,710$ & 0,787 \\
\hline Talent Development & 3,4690 & 1,27630 & $-0,116$ & $-0,824$ & 0,810 \\
\hline Talent Attraction & 3,9179 & 1,07055 & $-0,690$ & 0,118 & 0,791 \\
\hline \multicolumn{7}{|c|}{ SERVICE DELIVERY } & & \\
\hline Assurance & 4,1679 & 1,07055 & $-0,500$ & $-0,580$ & 0,659 \\
\hline Reliability & 3,4786 & 1,10050 & $-0,384$ & $-0,412$ & 0,946 \\
\hline
\end{tabular}

The results of the correlation analyses between talent management and service delivery are reported in Table 7 below. The results showed that all talent management practices are significantly positively related to the Reliability and Assurance dimensions of service delivery. 
Table 7: Results of the correlation analyses

\begin{tabular}{|l|c|c|}
\hline \multirow{2}{*}{ Talent Management Practices } & Assurance & Reliability \\
\hline Strategic Talent Management &, $389^{* *}$ &, $482^{* *}$ \\
\cline { 2 - 3 } & 0,000 & 0,000 \\
\hline Pempensation & $.197^{*}$ & $.252^{* *}$ \\
\cline { 2 - 3 } & 0,020 & 0,003 \\
\hline Talent Retention &, $323^{* *}$ &, $283^{* *}$ \\
\cline { 2 - 3 } & 0,000 & 0,001 \\
\hline Talent Development &, $401^{* *}$ &, $321^{* *}$ \\
\cline { 2 - 3 } & 0,000 & 0,000 \\
\hline Talent Attraction &, $218^{* *}$ &, $309^{* *}$ \\
\cline { 2 - 3 } & 0,010 & 0,000 \\
\cline { 2 - 3 } &, $382^{* *}$ &, $411^{* *}$ \\
\hline
\end{tabular}

* Statistically significant: $p \leq 0,01$

+ Practically significant correlation (medium effect): $r \geq 0,30$

++ Practically significant correlation (large effect): $r \geq 0,50$

The results showed a practically significant relationship with a medium effect between strategic talent management, performance management, talent retention, talent attraction and assurance. The results further showed a practically significant relationship with a medium effect between strategic talent management, talent retention, talent development and talent attraction. The above results imply that talent management, if effectively applied, will enhance the quality service delivery of the SAPS and vice versa. As with this study, the poor application of talent management practices reduces the ability of the SAPS to deliver reliable services.

From the above results, Hypothesis 1 is confirmed that Talent Management has a significant positive relationship with service delivery

\section{Discussion}

The main objective of this research was to determine the relationship between talent management and service quality of police officials. The results of this research showed amongst others that a talent management strategy for police officials are lacking. Consequently the SAPS will find difficulties in identifying, attracting and retaining the 
appropriate pool of talented individuals that can deliver the quality services required by the community (Faull, 2017). As with previous research, the results of the study showed that compensation and talent retention practices are poorly applied. According to Hewitts (2008) a high performance culture can only be achieved if individuals are rewarded appropriately. A lack of rewards enhances the turnover intentions of key and skilled employees (Makhuizeni \& Barkhuizen, 2015). The lack of talent retention strategies is a significant risk that threatens the sustainability and ability of the SAPS to ensure a safe society for citizens (Madimabe et al., 2017).

The participants of this study seemed somewhat satisfied with the performance management system of the SAPS. As mentioned by the Mondy et al. (cited in Makhuzeni \& Barkhuizen, 2015) the performance management system can assist to identify development opportunities for succession planning. In this study almost half of the participants perceived a lack of career development opportunities. Career development interventions and training are needed in the different stages of the talent life cycle to assist talented individuals to achieve their full potential. Career development opportunities are also important in retaining a competent South African police force (Lesenyeho, 2017).

The results of this research showed that talent management plays a significant role the ability of police officials to deliver quality service. The lack of talent management practices in this study resulted in reduced levels of service performance relating to assurance and reliability. Strategic talent management, talent retention and talent attraction practices appeared to have the greatest influence on service delivery. The results confirm previous findings that talent management plays a significant role in service delivery (see Barkhuizen et al., 2015; Scholastika \& Schutte, 2017). The above results re-emphases the need of the SAPS to develop talent management policies with clear strategies that will guide the institution in achieving its goals through its talented people.

This research makes important theoretical and practical contributions. From a theoretical perspective this study provides new empirically validated knowledge on talent management and its role in the service delivery of police officials. From a practical point of view this research highlighted problematic areas in the application of talent management that requires improvement. Of particular importance is the development and implementation of a talent management strategy that will guide the effective talent management of police officials from attraction to retention. 
This research had some limitations. First the sample included police officials from a selected geographical area. The results can therefore not be generalised to other police officials. Future research should be expanded to other provinces in South Africa and include police management in the sample to obtain a more holistic perspective on the application of talent management and the outcomes thereof for the police service. Secondly this research used a cross-sectional design with data gathered over a short period of time. Longitudinal research can be applied to track the application of talent management over a longer period of time to make cause and effect inferences. Finally future research can also include more antecedents (i.e. leadership) and outcome variables for talent management (i.e. well-being, turnover intentions) in the police services.

In conclusion, this research highlighted the importance of talent management in enabling the effective service delivery of police officials. Management should be empowered (educated and trained) in terms of issues relating to talent management such as:

- to attract, develop and retain talent in the SAPS in order to enhance service delivery;

- to adhere to relevant talent management strategies or policies; and

- to apply the correct mind-set to issues relating to effective talent management.

\section{References}

ABDUL-KAREEM, A., 2016. Best Practices for Talent Management: Critical Drivers for Organisational Success and Survival. European Journal of Business and Management. 2016, Vol. 8, No. 25, s. 98106.

BARKHUIZEN, E., 2015. Talent Management: The Catalyst for the 21st Century Business World.. [Online] Available at: http://www.nwu.ac.za/sites/www.nwu.ac.za/files/files/mc/documents/2015\%20\%20INAUGURAL\%20LECTURE\%20PROF\%20BARKHUIZEN.pdf Reprint 2015

BARKHUIZEN, E.N., SCHUTTE, N.E. and SMIT, A. 2015. Talent management, motivation and service quality of support staff in a public higher education institution.. Journal of Public Administration. 2015, Vol. 50, No. 1, s. 658-673.

BARKHUIZEN, E.N, WELBY-COOKE, G., SCHUTTE, N. and STANZ, K., 2014. Talent Management and Leadership Reciprocity: The case of the South African Aviation Industry. Mediterranean Journal of Social Sciences. 2014, Vol. 5, No. 9, s. 11-17.

CANNON, J. \& MCGEE, R., 2011. Talent management and succession planning. 2nd ed. London: Chartered Institute of Personnel and Development. Reprint 2011.

DU PLESSIS, L., BARKHUIZEN, E., STANZ, K. and SCHUTTE, N., 2015. The management side of talent: Causal implications for the retention of generation $Y$ employees. The Journal of Applied Business Research. 2015, Vol. 35, No. 1, s. 1767-1780. 
FAULL, A., 2017. The South African Police Service's code of conduct: A critical review, Cape Town: African Policing Civilian Oversight Forum (APCOF). Reprint 2017.

FIELD, A., 2009. Discovering statistics using SPSS. 3rd ed. London: Sage. Reprint 2009.

HAIR, J.F., BLACK, W.C., BABIN, B.J. and ANDERSON, R.E. 2010. Multivariate data analysis: A global perspective. 7th edn. Upper Saddle River, NJ: Pearson Education. Reprint 2010.

KOKETSO, L. 2011. Perceived challenges to talent management in the South African Public Service: An exploratory study of the city of Cape Town Municipality. Cape Town: Cape Peninsula University of Technology. Reprint 2011.

KUMAR, R. 2014. Research methodology: a step by step guide for beginners. 4th ed. Thousand Oaks: Sage. Reprint 2011.

KUMUDHA, A. and PRIYADARSHINI, S. 2016. A Conceptual study on challenges and Innovations in Talent Acquisition Process. International Journal of Advance Research in Computer Science and Management Studies. 2016, Vol. 4, No. 1, s. 168-173.

LEEDY, P. and ORMROD, J. 2015. Practical Research: Planning and design. 11th ed. Malaysia: Pearson. Reprint 2015.

LESENYEHO, D., 2017. Talent management of early career academics in merged South African higher education institutions.. Mmabatho: Department of Industrial Psychology, North-West University. Reprint 2017.

LYRIA, R. 2013. Role of Talent Management on Organızatıon Performance in Companıes Lısted in Naıbobı Security Exchange in Kenya: Literature Review. International Journal of Humanities and Social Science. Vol. 3, No. 21, s. 285-290.

MAGOLEGO, H., BARKHUIZEN, E.N. and LESENYEHO, D. 2013. Talent Management and Job Performance: The Mediating Role of Job Satisfaction.Johannesburg, PPBA, s. 132-235.

MASALE, R., BARKHUIZEN, E., MOKGELE, R. and MAKGALA, D. 2016. Talent management as a predictor of employee performance in local government institutions in Botswana. Langebaan, Nelson Mandela Metropolitan University, s. 227-240.

MASIAPATA, N. 2007. Ethics and ethos in the South African Police Service: An overview of the Johannesburg Central Station. Pretoria: Department of Public Administration, University of Pretoria. Reprint 2007.

MBATOBAKO, M. and BARKHUIZEN, E. 2017. Leadership Talent Mindset as a predictor of the motivation and retention of unior of correctional officials. Paper presented at the $34^{\text {th }}$ International Academic Conference, Florence, Italy.

MELLO, D. 2008. Human resource development for effective service delivery in the South African public service. Journal of Public Administration. 2008, Vol. 43, No. 1, s. 203-213.

MOGWERE, P., 2014. The relationship between talent management, employee engagement and service quality of support staff in a South African higher education institution. Mmabatho: Department of Industrial Psychology, North-West University. Reprint 2014. 
NAFEI, W. 2015. The Effects of Talent Management on Service Quality: A Study on Commercial Banks in Egypt. International Business Research. 2015, Vol. 8, No. 4, s. 41-58.

NCUBE, C., 2016. Mediating the relationship between talent management practices and intention to quit.. Johannesburg: University of the Witwatersrand. Reprint 2016.

NTHEBE, K., BARKHUIZEN, E. and SCHUTTE, N., 2016. Rewards: A predictor of well-being and service quality of school principals in the North-West Province. South African Journal of Human Resource Management. 2016, Vol. 14, No. 1, s. 1-11.

PARASURAMAN, A., ZEITHAML, V. and BERRY, L. 1990. SERVQUAL: A multi-item scale measuring customer perceptions of service quality. Journal of Retailing. 1990, Vol. 64, No. 1, s. 12-42.

PAULSEN, R. 2008. Levels of stress and coping strategies employed by police service officers in Cape Town, South Africa. Cape Town: Department of Psychology, University of the Western Cape. Reprint 2008.

SCHUTTE, N. \& BARKHUIZEN, E. 2016. Talent Management in Low Performing Organisations: Challenges and Solutions. Paper presented at the $34^{\text {th }}$ International Business Research Conference, London, UK.

SCHWARTZ, G., SCHURINK, W. and STANZ, K. 2007. Frontline Police Employees' Social Construction of Client Service. SA Journal of Human Resource Management. 2007, Vol. 5, No. 3, s. 38-47.

SOUTH AFRICAN POLICE SERVICE, 2015. Strategic Plan, South African Police Service, 2014-2019, Pretoria: SAPS Strategy, Research, Monitoring and Evaluation. Reprint 2015.

SPSS, 2017. SPSS 24.0 for Windows. Chicago: SPSS Inc. Reprint 2017.

STRAUSS, M. 2012. Exploring the factor for attracting and retaining teachers to rural areas. Pretoria: Department of Human Resource Management; University of Pretoria. Reprint 2012.

THERON, M., BARKHUIZEN, E.N. and DU PLESSIS, Y. 2014. Managing the academic talent void: Investigating factors in academic turnover and retention in South Africa. South African Journal of Industrial Psychology. 2014, Vol., 40, No. 1, s. 1-14.

VAN DIJK, H. 2008. The talent management approach to Human Resource Management: attracting and retaining the right people. Journal of Public Administration. 2008, Vol. 43, No. 3, s. 385-395.

VILAKAZI, M. 2015. The impact of police corruption on service delivery in Pretoria Central. Pretoria: University of South Africa. Reprint 2015. 